This item was submitted to Loughborough's Research Repository by the author.

Items in Figshare are protected by copyright, with all rights reserved, unless otherwise indicated.

\title{
Learning by bumping: Pathways of Dutch SMEs to foreign direct investment in Asia
}

PLEASE CITE THE PUBLISHED VERSION

https://doi.org/10.1111/tesg.12121

\section{PUBLISHER}

Wiley () Royal Dutch Geographical Society KNAG

VERSION

AM (Accepted Manuscript)

\section{PUBLISHER STATEMENT}

This work is made available according to the conditions of the Creative Commons Attribution-NonCommercialNoDerivatives 4.0 International (CC BY-NC-ND 4.0) licence. Full details of this licence are available at: https://creativecommons.org/licenses/by-nc-nd/4.0/

\section{LICENCE}

CC BY-NC-ND 4.0

\section{REPOSITORY RECORD}

Van Meeteren, Michiel. 2019. "Learning by Bumping: Pathways of Dutch Smes to Foreign Direct Investment in Asia”. figshare. https://hdl.handle.net/2134/37039. 
Asia

Michiel van Meeteren ${ }^{1}$

Department of Geography, Ghent University

Krijgslaan 281/S8 (WE 12)

9000 Gent, Belgium

E: Michiel.vanMeeteren@UGent.be

T: +329264 4697

Published as: Meeteren, M. (2015). Learning by Bumping: Pathways of Dutch Smes to Foreign Direct Investment in Asia. Tijdschrift voor Economische en Sociale Geografie, 106(4), 471-485. Please refer to the published version.

\section{ABSTRACT}

This paper investigates how eleven Dutch Small and Medium-sized Enterprises (SMEs) transnationalized with East- and Southeast Asian economies by means of establishing a foreign subsidiary. The study's aim is to elucidate how firms learned to become a transnational corporation and to gauge the relevance of the firm's external networks in the acquisition of the appropriate knowledge. The paper conceptualizes SME transnationalization as an organizational process that can be understood by theories developed in innovation studies. Through qualitative research on transnationalization pathways, inferences are drawn on the skills and routines that are necessary to bridge institutional differences and the process by which these skills are acquired and routinized within the firm.

\footnotetext{
${ }^{1}$ I would like to thank Arash Aazami and Peter Pelzer for their indispensable work as research assistants. David Bassens, Ben Derudder, Pieter Tordoir, Judith Verweijen, and three reviewers provided valuable feedback that helped improve the paper. 
Keywords: Transnational entrepreneurship, SMEs, foreign direct investment, embeddedness, organizational innovation, critical incident technique,

\section{INTRODUCTION}

Traditionally, transnationalization by means of establishing foreign subsidiaries was only considered feasible for large corporations due to the high risks and transaction costs involved (Caves 2007). Recently, however, there has been a steep rise in the number of transnationalized Small and Medium-sized Enterprises (SMEs) (OECD 2008), coinciding with a surge of Foreign Direct Investment (FDI) in East and Southeast Asia (UNCTAD 2010). Nevertheless, SMEs often lack the financial resources to 'buy themselves in' into these, from a European perspective, more distant contexts. Consequently, even within a small open economy such as the Netherlands, the majority of SMEs' FDI tend to stay within the boundaries of the European Union (Hessels 2005).

This paper aims to contribute to a better theoretical understanding of successful transnationalization by SMEs to institutionally dissimilar environments. In an explorative empirical study based on in-depth corporate interviews, qualitative company network mapping and an application of the critical incident technique, it is investigated how eleven Dutch SMEs learned to transnationalize with East or Southeast Asia. Rather than focusing on the specificities of Asian business systems, the paper sets out to understand how SMEs, with their limited resources, are able to acquire knowledge of social and institutional contexts that are profoundly different from those in their country of origin. 
The paper is structured as follows. Building on Hess's (2004) reconceptualization of embeddedness and Yeung's (2009) theorizing of transnational entrepreneurship, the next section proposes an integrative framework that recasts existing theories of firm transnationalization as an organizational innovation process. It argues that such a process involves a successful fusion of different bodies of knowledge about institutional environments that a firm needs to master in order to be able to re-embed itself in a transnational context. After the research strategy and methodology have been elaborated, a successive section investigates the intra-firm dimensions of learning how to transnationalize. The paper subsequently shifts to the inter-firm perspective and gauges the relevance of the firm's business network in the transnationalization process. Finally, the paper concludes by joining the empirical findings with the discussed theoretical perspectives on firm transnationalization.

\section{INTEGRATING SME TRANSNATIONALIZATION THEORY}

In this paper, transnationalization is understood as the process of becoming a transnational corporation (TNC). Following Dicken (2011, p.110), a TNC is in turn defined as "a firm that has the power to coordinate and control operations in more than one country, even if it does not own them" ${ }^{2}$. When transnationalizing, a firm has to overcome its 'liability of foreignness' (Hymer 1976), which refers to a firm's unfamiliarity with an institutional environment different from its home environment. These institutional differences amount to a varied collection of knowledge deficits for the transnationalizing firm. The firm needs to become acquainted with different business conventions, different ways of building relations of trust with suppliers and clients, different legal systems, different market preferences, and in a more general sense, has to cope with different cultures and their underlying value systems (Hofstede 2001; Van Houtum 2002). In sum,

\footnotetext{
${ }^{2}$ Note that this paper focuses only on a particular subset of small and medium-sized TNCs, namely those for which the transnationalization process ultimately resulted in establishing a foreign subsidiary.
} 
the firm's sufficient embeddedness in different institutional contexts is crucial for doing business. A firm acquires this institutional knowledge and related skills through interactions with others. Therefore, embeddedness in networks of social relations matters as well (Granovetter 1985). Moreover, since knowledge on how to do business in different contexts is not equally distributed across entities and spaces (Stam, 2010), the availability of social and cognitive resources necessary to transnationalize is a highly geographic affair.

In international business studies, both network and institutional perspectives have been proposed for research on transnationalization. (cf. Pflanz 2013). However, signaling a wider divide between institutional and resource-based perspectives in business studies (Oliver 1991), these approaches are often regarded competing rather than complementary (Ellis 2000). Hess's (2004) analytical distinction between societal, network and territorial embeddedness allows us to juxtapose these perspectives. Whereas societal embeddedness refers to the institutional and knowledge properties of firm transnationalization, network embeddedness refers to the relational and social network aspects. Territorial embeddedness shifts the focus to the geographical properties of the societal and network features.

The Uppsala theory of firm transnationalization (Johanson \& Vahlne 1977) can be considered a 'baseline theory' of institutional perspectives on firm transnationalization (see Ellis 2000). The theory states that firms cope incrementally with the liability of foreignness -theorized with the concept of 'psychic distance'- through an evolutionary learning process. Transnationalization involves a step-wise dual process of growing commitment to the new host market and enhanced experiential knowledge within the firm. Stages typically include export relations, the establishment of a representative office, and eventually, the 
creation of a full foreign subsidiary. The Uppsala theory infers that firms tend to first transnationalize to countries that are relatively similar culturally, and hence usually geographically proximate, since the psychic distance with those countries is assumed to be lower.

While the Uppsala model has been extensively employed in research on transnationalizing SMEs (see Coviello \& McAuley 1999), it has also been challenged. Accounts of transnationalization in a globalized age (e.g. Mathews \& Zander 2007) defy the logic of incremental transnationalization to culturally proximate countries: firms leapfrog the early stages of exporting that allegedly precede the creation of a foreign subsidiary. Furthermore, these accounts posit that host country choice seems to be relatively culturally independent from the companies' home country (Ellis 2000; Chetty \& Holm 2000). However, these new theories of transnationalization do not challenge the basic claim that a firm needs to acquire knowledge about distant environments. Rather, they stress that processes associated with globalization have altered the possibilities for successful acquisition of that knowledge (Prashantham 2005; Mejri and Umemoto, 2010).

Criticisms of the Uppsala school have shifted the subject of research from the stock of knowledge necessary for transnationalization to the sources of that knowledge; the socalled 'network approach' (Coviello \& Munro, 1995; Tolstoy 2010). The research carried out within this approach tends to study the structure of social and inter-firm networks rather than the knowledge conveyed through them (Ellis 2000; Chetty \& Holm 2000, Bathelt \& Glückler 2012). As a result, Johanson \& Vahlne (2009) from the Uppsala school reformulated their original model; they now suggest that instead of overcoming liability of foreignness, transnationalization entails subduing 'liability of outsidership'-being excluded from these network resources. Despite Johanson \& Vahlne's new emphasis on the 
structure of the firm's external network, one should be wary of equating the structure of the network with the content and not overlook the enduring importance of the knowledge shared. There might be different pathways to obtain the same knowledge. These two different kinds of liabilities -foreignness and outsidership- correspond neatly to the lack of different kinds of embeddedness. The liability of foreignness refers to the lack of societal embeddedness of the transnationalizing firm, whereas liability of outsiderness refers to the lack of network embeddedness.

Transnational entrepreneurship as an innovation process- Yeung (2009) proposes a multi-dimensional theory of transnational entrepreneurship to understand the economic geography of firm transnationalization. Firstly he states that: "A transnationalizing entrepreneur may interpret a risk in 'foreign' business systems (perceived by most corporate managers) as an opportunity. This transnationalizing entrepreneur is able to make such critical judgements precisely because of his or her performative foresights and access to peculiar entrepreneurial networks and resources" (Yeung 2009, p. 227). Thus, actors differ in their degree of network embeddedness due to their position in global production networks. Simultaneously, these actors have varying performative foresights, which ultimately relate to profitable combinations of knowledge about different business systems, highlighting their societal embeddedness (cf. Drori et al. 2009; Kloosterman 2010). Secondly, Yeung argues that the creation of a transnational enterprise acts as a disequilibrating force on the economic system through which value can be created and appropriated. It can thus be conceived of as an organizational innovation increasing the competitive position of the focal firm (Yeung 2009, p. 215, c.f. Bilkey \& Tesar 1978). Thirdly, Yeung's approach highlights that such an innovation has the potential to alter the economic geography of two previously less connected localities, disrupting the playing field for other firms (Yeung 2009, p. 214). 
When approaching transnationalization as an innovation process, it becomes important to conceptualize the enabling technology. Kogut and Zander (1993, p. 626) argue that a firm can be regarded as an organizationally bounded "social community whose productive knowledge defines a comparative advantage". This definition is congruent with seeing a firm as a constellation of communities of practice or a combined pool of human resources (Wenger 1998; Amin \& Cohendet 2004). The collective productive knowledge of these communities consists of, among other things, technological knowledge, market knowledge, and managerial knowledge. These bodies of knowledge and their combinations institutionalize in the routines of a firm (Nelson \& Winter 1982). These routines are embodied, performed, and reproduced by the firm's constituent communities of practice. Therefore, a firm's routines encompass institutional knowledge of how to do business within a particular environment. Such a body of knowledge is experienced as 'common sense' regarding conventions and institutions within the firm (Berger \& Luckmann 1966; cf. Storper 1997). Geographically differentiated patterns in these conventions and institutions have long been studied in the literatures on varieties of capitalism and business systems (see Whitley 1992; Boyer 2005). This knowledge is often gathered by means of a process of 'learning by doing' through practice and experimentation within the operating environment (Jones \& Murphy 2011). As such, the day-to-day practices of a firm are strongly influenced by the macro-cultural and institutional environment that a firm is 'born' in. This socialization into the operating environment is quite often not a conscious process (Gertler 2001; 2003a). Routinization implies that knowledge about the genesis of the firm's habitual actions can get lost in the replication of routines (Maskell \& Malmberg 2007). In becoming 'common sense', knowledge can lose some of its reflexivity. What is relevant for the current inquiry is that for a company to do business in any environment, it is a necessary requirement to have internalized a stock of institutional knowledge of that 
environment: its societal embeddedness. This is embodied in the routines of a firm and its constituent social communities, exemplifying how societal and network embeddedness are co-constitutive. Transnationalization thus entails a firm that re-embeds itself by mastering a 'new combination' of two distinct bodies of knowledge about 'home' and 'host' institutions. This knowledge tends to be tacit, since it is difficult to communicate, context specific, and often to a large extent unconsciously processed (Gertler 2008).

\section{RESEARCH STRATEGY}

The three dimensions of embeddedness discussed above, namely societal, institutional and territorial embeddedness, translate into two broad research questions that must be answered to promote our understanding of SME transnationalization. First, what are the knowledge, skills and practices utilized by an SME to transnationalize and how are these implemented in the organization? Second, how is the acquisition of that knowledge and skills related to the internal communities of practice and the external business network of a firm, and its associated geographies? Although the literature emphasizes that knowledge frequently traverses organizational boundaries (Dicken 2011, p. 121), this study follows Oinas (2006) in her argument that the organizational boundaries of the firm remain of crucial importance for understanding firm behavior. Hence, the level of the firm is the main level of analysis by which the research findings are presented.

The population of interest for this study consists of Dutch SMEs that have successfully established a foreign subsidiary in an emerging economy in East- or Southeast Asia. As there is no usable sampling frame to identify and randomly select transnational SMEs in the Netherlands, the research relied on non-randomized sampling methods. First, four preliminary interviews were conducted with specialists from the Amsterdam chamber of commerce, the Dutch federation of exporters (FENEDEX), a bank specialized in direct 
investment in the Global South (FMO) and an Asian transnationalization consultant. These provided important contextual knowledge and allowed for refinement of the research design. The second phase consisted of eleven extensive semi-structured interviews with eligible Dutch SMEs combined with background desk research for each case, which were conducted between June 2010 and April 2011. Three cases were identified through the networks of the experts, five through an extensive national newspaper and specialized literature search, and three were snowball sampled through other companies interviewed. The interdependencies between the cases where snowball sampling had been utilized were specifically probed to estimate the independence of each case in order to maximally correct for bandwagon effects between respondents. Through the heterogeneity in terms of sector, age and size and independence of the cases researched, a sample was obtained that was suitable for a case study based on a diverse case study method (Gerring 2007, pp. 91-101). Such a case study allows for elucidating the full variety of independent variables that help us understand an outcome shared across cases; i.e. the event of transnationalization by foreign direct investment. Moreover, commonalities shared by heterogeneous cases provide an indication of the wider significance of the causal mechanisms identified. Such a technique is appropriate for achieving a high degree of confidence in the validity of the observed mechanisms in the sample, but is less suited to make generalized statements about an unobserved population. As such, it prioritizes the generation of plausible hypothesis among a limited sample over statistical generalization to a wider population (Gerring 2007).

The primary method of the study was the qualitative corporate interview (Schoenberger 1991). Each case was investigated by intensive interviews with (a) key person(s) in addition to substantive desk research. Key persons were considered to be those who were personally involved in establishing the transnational enterprise, usually on the executive level. A significant advantage of researching SMEs compared to larger-scale firms is that 
they have a relatively straightforward organizational structure and that an extended interview with a single key person can provide a rich picture of the organization's practices and interactions. The qualitative corporate interview works as a 'close dialogue' between researcher and interviewee that allows the researcher to align theoretically informed concepts with the practical experiences and discourses of the respondents (Clark 1998). It provides sufficient flexibility to 'bend' the research design to encompass the variation of relevant factors found in the field. In the interviews, the relevant life history of the firm was probed by applying the 'critical incident technique' (Chell 2004; Stam 2007). Key incidents regarding the transnationalization process, ranging from formal achievements to 'light bulb moments', were identified, and associated actors and stories subsequently probed. Such a longitudinal perspective on the history of the firm is necessary since the relevance of external connections differs throughout its life course (Stam 2007) -some become redundant, while others become internalized. Comparing these critical incidents and their associated relations to actors or institutions informed the systematic comparison of cases in the data analysis phase. The rather formalized critical incident procedure was complemented with an open semi-structured interview to understand the strategy, structure, and daily functioning of the firm, which was needed to obtain sufficient background information. Each interview was concluded with the co-creation of a 'participant-aided sociogram' (Hogan et al. 2007) of the firms' current external networks. Interviews had an average length of two hours and were fully transcribed. The transcriptions, together with the co-created visualizations of the critical incident technique and company network maps were analyzed with qualitative data analysis software. 
Table 1. Descriptive features of cases

\begin{tabular}{|c|c|c|c|c|c|}
\hline $\begin{array}{l}\text { Firm } \\
\text { no. \# }\end{array}$ & Industry & $\begin{array}{c}\text { Total } \\
\text { Workforce }\end{array}$ & $\begin{array}{l}\text { (South)east } \\
\text { Asian subsidiary }\end{array}$ & $\begin{array}{l}\text { Other foreign } \\
\text { subsidiaries }\end{array}$ & $\begin{array}{l}\text { Year of first } \\
\text { Asian subsidiary }\end{array}$ \\
\hline 1 & Wood & $11-50$ & China (PRC) & - & 2000 \\
\hline 2 & $\begin{array}{l}\text { Financial } \\
\text { services }\end{array}$ & $11-50$ & Vietnam & - & 2010 \\
\hline 3 & Machinery & $51-200$ & China (PRC) & - & 2008 \\
\hline 4 & Plastics & $51-200$ & China (PRC) & France, USA & 2007 \\
\hline 5 & $\begin{array}{c}\text { Machine } \\
\text { components }\end{array}$ & $51-200$ & China (PRC) & - & 2003 \\
\hline 6 & $\begin{array}{l}\text { Outsourcing } \\
\text { services }\end{array}$ & $1-10$ & China (PRC) & - & 2006 \\
\hline 7 & $\begin{array}{l}\text { Outsourcing } \\
\text { services }\end{array}$ & $11-50$ & China (PRC) & - & 2006 \\
\hline 8 & Agriculture & $201-250$ & Vietnam & India & 1997 \\
\hline 9 & Plastics & $11-50$ & China (PRC) & - & 2005 \\
\hline 10 & $\begin{array}{c}\text { Machine } \\
\text { components }\end{array}$ & $201-250$ & Malaysia & Turkey & 2009 \\
\hline 11 & Furniture & $51-200$ & $\begin{array}{c}\text { Malaysia, China } \\
\text { (PRC) }\end{array}$ & $\begin{array}{c}\text { Australia, } \\
\text { USA }\end{array}$ & 1998 \\
\hline
\end{tabular}

Table 1 shows the most important anonymized descriptive features of the studied firms. All Asian subsidiaries surveyed are greenfield investments. The firms are quite heterogeneous as regards sector, size and date of establishment, with an emphasis on manufacturing sectors and China as host country. This was not intentional and due to the lack of a sampling frame, it is unknown to what extent this distribution is representative for eligible Dutch SMEs. The firms categorized under 'outsourcing services' are companies specialized in sourcing and producing goods in Asia for third parties.

Before elaborating the research findings, it is important to clarify some of the limits inherent to the methodological choices made prior to this study's fieldwork. The primary aim of the study was to understand the interplay of network and societal embeddedness, 
rather than hierarchize different causal mechanisms of firm transnationalization. A formal test comparing different causal mechanisms would require a different research design and sampling frame. Since this study has only observed cases that ultimately resulted in foreign direct investments, other mechanisms might be more salient when other modes of transnationalization such as exports or joint-ventures are put center stage. However, the process of transnationalization of the researched firms often did involve intermediate stages of exporting and sales through intermediaries that proved important in the transnationalization process. Finally, the research design prohibits making definite statements about the differences between SMEs of different sizes and large TNCs. The relatively simple organizational structure and limited financial resources of the SMEs studied in this paper tend to highlight the technological and entrepreneurial features of transnationalization rather than the political-economic considerations that will play a bigger role in large TNCs. Nevertheless, one can assume that comparable processes can be found in such TNCs, albeit hidden in a more complex division of labor.

\section{FIRM LEVEL DYNAMICS}

Acquiring cultural reflexivity: learning to learn by bumping- The interviews yielded rich data on the types of cross-cultural encounters that the respondents faced, such as gradually learning the social skills to get a supplier contract with an Asian lead firm, learning how to procure good quality raw materials, or dealing with the different authority conventions that come with employing Asian workers (cf. Hughes 2009). It is not the aim of this paper to draw conclusions on the specificities of these institutional differences. Rather, it focuses on the skills necessary to learn about these different environments or business systems. Business systems differ strongly amongst East and Southeast Asian societies (Whitley, 1992) and show significant differences between sectors. Moreover, they are rapidly evolving as the region develops. As a respondent stated "if you read a book about 
doing business in China and it is older than five years, you should regard it as a history book". Business practices in East and Southeast Asia evolve and hybridize faster than we can study them, although they are bound to remain distinct from their equivalents in Europe or the United States (Gertler 2001; Yeung 2004; Meyer et al. 2009). This strong dynamic in evolving practices potentially aggravates the liability of foreignness. One has to learn the properties of a moving target, which increases the tacit character of the knowledge involved.

To understand how a firm learns to cope with a new socio-spatial environment, the empirical findings are related to Kogut and Zanders' (1993; 1996, c.f. Nelson \& Winter, 1982) knowledge-based evolutionary theory of the firm. The ability to smoothly exploit business opportunities relies on an alignment of cognitive understandings of the situation at hand amongst the firm's communities of practice, which renders their cognitive distance low (Kogut \& Zander 1996; Nooteboom 2000). However, for innovation, a firm needs to engage in exploration, as opposed to exploitation. It needs to absorb new knowledge and possibly implement it in the firm's routines. This requires a higher cognitive distance between communicating agents, who nevertheless need to retain a shared base of understanding in order to communicate effectively (Nooteboom 2000). Cognitively, this implies that an organization needs prior related knowledge to be able to pursue new discoveries on a particular subject (Cohen \& Levinthal 1990). Across the cases studied, this univocally boiled down to the skill of an organization to reflexively identify cultural and institutional differences and their underlying logics. The interviewees stressed across the board that one does not only have to identify what is different between the two environments a firm operates in: the differences in conventions, authority structures, the political system etcetera, but one also needs to develop sensitivity as to why people behave the way they do. For example, one respondent stated that: 
"There are different ways of thinking: Western thinking and Chinese thinking, so they have different norms. In the Netherlands and Europe we just assume that our behavior is 'normal'- $100 \%$, and everything else is 'different'. When you are in China, you have to 'translate' the culture. I might be annoyed by people's behavior, but maybe they are annoyed by me as well. Maybe this is normal and I have to get used to it. You have to learn to recognize these sorts of situations. You have to acknowledge that the rules are different" - Firm \#7.

This quote illustrates the belief, shared to a significant degree among respondents, that successful transnationalization requires recognizing that the home culture is just one way of doing things and that other economic environments have different but often equally 'rational' logics. It is therefore necessary to 'denaturalize' the home environment, and recognize that different environments have different commonsensical routines to carry out daily practice. In doing so, the firm implicitly or explicitly acknowledges that it is embedded in certain institutions and that this embeddedness influences how situations are defined. From this acknowledgement follows the realization that other institutional environments might work according to different principles, but that a firm can develop the capability to 'translate or broker' between environments; a firm develops 'mixed embeddedness' (Kloosterman 2010; cf. Drori et al., 2009). The key persons/entrepreneurs had developed ethnographic skills although they did not define it in that particular jargon. It appears that most of them had acquired these skills in daily practice, for they all emphasized the importance of 'learning by doing', or as one respondent put it: "learning by bumping your head against a brick wall". Learning by bumping entails making mistakes in communication or procurement, coupled with an active inquiry on why a particular experience went 'wrong'. This process implies making tacit cultural knowledge explicit and therefore communicable. Respondents stressed the importance of explicitly asking their local personnel to teach them what they did wrong in a particular situation in order to avoid such gaffes in the future. Moreover, the companies which had subsidiaries in several countries 14 
stressed that once you have acquired these cross-cultural competencies, subsequent transnationalizations in another environment become easier: the context differs but the process of translation is comparable. There was consensus among respondents that you have to avoid full acculturation in the new environment. Understanding cultural differences provides a foundation upon which you can build by incrementally aligning your business practices with those of your foreign workers. You should be able to perform native modes of practice but always be wary of 'going native'. This results in hybrid practices rather than full acculturation. It shows the interrelation between societal and network embeddedness in the daily practice of the transnationalization process. The institutional knowledge is learned and hybridized through interacting in social networks of local personnel, but at this point, it is often not yet part of a firm's wider organizational routines.

Extending the knowledge throughout the organization -The routinization of new institutional knowledge points to the complicated process of how to forge the different subsidiaries of a company into an effective community. In this regard, Nooteboom (2008, p.132) stresses the role of 'boundary spanners' (BS), i.e.: "actors who are able both to collaborate with the people of their own group and the BS of the connecting group". All of the firms studied had a boundary spanning construction between the focal entrepreneur and a confident abroad at some point of the transnationalization, usually personified in the management of the new subsidiary. Table 2 summarizes this BS function for each of the firms studied, indicating the BS's previous experience in the respective host or home cultures, and where they were recruited. 
Table 2. Boundary Spanners (BS) of researched firms

\begin{tabular}{|c|c|c|c|c|}
\hline $\begin{array}{l}\text { Firm } \\
\text { no. \# }\end{array}$ & $\begin{array}{c}\text { Asian } \\
\text { subsidiary }\end{array}$ & BS source & $\begin{array}{l}\text { Nationality } \\
\text { BS }\end{array}$ & $\begin{array}{l}\text { Experience with } \\
\text { home/host culture }\end{array}$ \\
\hline 1 & China (PRC) & $\begin{array}{l}\text { Former contact } \\
\text { person at supplier }\end{array}$ & Chinese & Trading experience \\
\hline 2 & Vietnam & Personal friend & Dutch & Married to Vietnamese \\
\hline \multirow[t]{2}{*}{3} & China (PRC) & \#1 Former intern & Chinese & $\begin{array}{l}\text { Worked in TNCs in Asia, } \\
\text { studied in the Netherlands }\end{array}$ \\
\hline & & $\begin{array}{l}\text { \#2 Recruited with } \\
\text { help of \#1 }\end{array}$ & Chinese & $\begin{array}{l}\text { Studied in the UK, former } \\
\text { agent of European TNC }\end{array}$ \\
\hline \multirow[t]{2}{*}{4} & China (PRC) & $\begin{array}{l}\text { \#1 Contact person at } \\
\text { distributor/agent }\end{array}$ & Chinese & Trading experience \\
\hline & & $\begin{array}{c}\text { \#2 ‘Team' recruited } \\
\text { by recruitment } \\
\text { agency }\end{array}$ & Chinese & $\begin{array}{c}\text { Extensive interaction with } \\
\text { entrepreneur }\end{array}$ \\
\hline 5 & China (PRC) & $\begin{array}{l}\text { Former contact } \\
\text { person at } \\
\text { distributor/agent }\end{array}$ & Chinese & Studied in the Netherlands \\
\hline 6 & China (PRC) & $\begin{array}{l}\text { Recruited through } \\
\text { personal network }\end{array}$ & Dutch & Married to Chinese \\
\hline \multirow[t]{2}{*}{7} & China (PRC) & $\begin{array}{l}\text { \#1 First employee } \\
\text { recruited through } \\
\text { personal network }\end{array}$ & Chinese & $\begin{array}{l}\text { Extensive interaction with } \\
\text { entrepreneur }\end{array}$ \\
\hline & & $\begin{array}{l}\text { \#2 'Team' recruited } \\
\text { by personal network }\end{array}$ & Chinese & $\begin{array}{c}\text { Extensive interaction with } \\
\text { entrepreneur }\end{array}$ \\
\hline \multirow[t]{2}{*}{8} & Vietnam & $\begin{array}{c}\text { \#1 Government } \\
\text { prescribed 'trading } \\
\text { partner' }\end{array}$ & Vietnamese & None \\
\hline & & $\begin{array}{l}\text { \#2 Recruited through } \\
\text { recruitment agency }\end{array}$ & Dutch & $\begin{array}{c}\text { Experienced local TNC } \\
\text { manager }\end{array}$ \\
\hline \multirow[t]{3}{*}{9} & China (PRC) & $\begin{array}{l}\text { \#1 Serendipitous } \\
\text { meeting in hotel }\end{array}$ & Chinese & $\begin{array}{c}\text { Extensive interaction with } \\
\text { entrepreneur }\end{array}$ \\
\hline & & $\begin{array}{l}\text { \#2 Recruited through } \\
\text { personal network }\end{array}$ & Dutch & Married to Chinese \\
\hline & & $\begin{array}{l}\text { \#3 Recruited through } \\
\text { personal network }\end{array}$ & Singaporean & $\begin{array}{c}\text { Experienced local TNC } \\
\text { manager }\end{array}$ \\
\hline 10 & Malaysia & $\begin{array}{l}\text { Recruited through } \\
\text { personal network }\end{array}$ & Singaporean & $\begin{array}{c}\text { Experienced local TNC } \\
\text { manager }\end{array}$ \\
\hline 11 & $\begin{array}{c}\text { Malaysia, } \\
\text { China (PRC) }\end{array}$ & $\begin{array}{l}\text { Recruited through } \\
\text { personal network }\end{array}$ & Chinese & $\begin{array}{l}\text { Speaks Dutch, worked in } \\
\text { the Netherlands }\end{array}$ \\
\hline
\end{tabular}

In table 2, 'extensive interaction with entrepreneur' means that the transnationalizing entrepreneur, usually the key person interviewed, spent at least several months in daily face-to-face interaction with the BS in Asia. This is also true for the 'teams' designation, 
which refers to a situation in which host-country employees were intensively trained in a mutual learning process with the key person. The 'experienced local TNC managers' are people who had previous experience running foreign subsidiaries abroad and were often recruited especially for that reason. Alternatively, in the cases \#1, \#4 and \#5, the BS was recruited from an existing contact with an agent or supplier abroad. Usually, the initial BS was the first employee in the new Asian subsidiary. It was not exceptional that they incrementally grew into this role by carrying out increasingly responsible tasks for the firm in the early orientation phase of the transnationalization. In cases \#7, \#8 and \#9, the firms had to replace their BS at a certain point. In the case of Dutch expats, this had to do with personal reasons, but in the other cases this succession originated in a professionalization of the company, which the BS could not keep up with. However, all firms acknowledged the BS's crucial role in the early phases of the transnationalization.

Except for the category 'extensive interaction with entrepreneur', cases \#4, \#7, and \#9, and the first partner of firm \#8, all BS had intensive exposure to the respective alien home or host-countries' culture through either their private situation, by studying abroad, or by intensively working with non-Asian companies. They were also equipped with the necessary bilingual skills: English and the local language. This reflects that BS perform indispensable functions by diminishing the liability of foreignness. They have responsibilities in the management of the subsidiary, have to translate the firm's strategy to the local context and provide the company with the means to find and evaluate local suppliers and/or customers (Vernon 1979). As a result, they have considerable agency to make the enterprise either a success or a failure (Buckley 1989). The dependency on the BS even extends to the physical traits of the entrepreneur. Several respondents stressed that their 'whiteness' hampered their ability to negotiate in Asia, making negotiation a responsibility of the BS to offset that liability. This means that trusting the BS and their 
loyalty to the company were particularly important for most of the firms, especially in the context of Asian business systems with their sometimes patchier legal institutions. This was indicated by respondents' emphasis on internalizing the BS in their company, through either labor or equity contracts. For example, all BS who were initially outside the firm eventually got hired.

As the foreign direct investment takes full shape it becomes almost impossible, and very risky, to organize the firm around one transcontinental linkage between two individuals. Therefore, the interactions, including tacit knowledge transfer and trust-building, eventually have to be extended to other members of the firm. Accountants start to communicate with accountants in the new institutional context or engineers have to collaboratively troubleshoot on technical issues. To enable such collaborations, the interacting parts of the organization have to be socialized in a shared context, in this way becoming a community of practice (Amin 2003; Amin \& Cohendet 2004). In the past, geographers would have argued that these are exactly the sorts of interactions that require geographical proximity, as this allows for the organization of sufficient communicational bandwidth to successfully 'forge' such a community. In recent years, the notion that geographic proximity is to a certain extent a proxy for relational proximity has gained currency (Amin \& Cohendet 2004; Boschma 2005; Ibert 2010). Actively lowering cognitive distance through proactive behavior by the firm can offset the organizational problem of being physically distant. Gradually, more and more employees are socialized as boundary crossers, which allows for increased remote learning within the transnational organization (Coe \& Bunnell 2003). Nevertheless, all respondents stressed the indispensability of Information and Communication Technologies (ICTs) to overcome distance and attain relational proximity. 
Between the focal entrepreneur and the BS, telephone or Skype contact is a daily endeavor and there is a continuous flow of emails between actors within the organization. Furthermore, most companies use advanced Enterprise Resource Planning (ERP) software to coordinate the company's daily operations. But ICTs alone were generally not deemed to be sufficient for maintaining contact. On average, the respondents stated to visit Asia six times a year, in particular to arrange those things that are best done face-toface. This concerned important negotiations, but also managing the more personal aspects of a business relationship. Furthermore, most companies brought their BS, but also other host country employees, regularly to the Netherlands in order to socialize them into the local company culture and train them in the company's practices. Conversely, Dutch employees were sent to Asia to jointly create business routines with their Asian counterparts. In general, respondents emphasized the importance of the personal dimensions of these sorts of interactions, as illustrated by the following quote:

"When people have not met in person and have not been at the foreign location they tend to misunderstand each other and problems escalate way faster. We noticed that when I saw our financial controller have an avalanche of emails, increasingly showing anger and frustration, with her Chinese counterpart. I then suggested her to go to China and it turned out that they quite liked each other in person. Ever since they have been able to cooperate empathically."- Firm \#4.

This is in line with what Faulconbridge (2006; 2007) found in his research on inter-location cooperation within transnational law firms. Through a combination of infrequent face-toface contact and frequent email and phone contacts, interpersonal ties are formed in physically distant collaboration. In order for SMEs to do this successfully, the entrepreneur has to convert his or her transcultural collaboration skills into company strategy, either explicitly by codifying the strategy or implicitly by setting a good example for other employees, as illustrated below. 
"We try to create a mentality in the organization which states 'our colleagues in Malaysia'. You can run into them in the plant here and you have to do something with them. That is a totally different mentality than thinking in terms of some foreign semi-supplier of which you happen to own the stocks. That change in company culture requires continuous effort. There are always colleagues whose English is bad and then you have to answer the phone to someone you hardly understand. To regard that person a colleague and put effort in understanding him or her requires a total change of mindset."- Firm \#10.

The entrepreneurial work undertaken within the company to embed itself transnationally can be illustrated by a pattern that was found amongst older firms with an industrial history. In those firms, workers were said to be aware of narratives of outsourcing and related job loss and therefore tended to be suspicious towards transnationalization plans that involve subsidiary establishment. A foreign direct investment strategy is therefore also a company identity project (White et al. 2007, cf. Battilana et al., 2009) and a trial run for the entrepreneur's interpersonal management skills. The quote below illustrates that this entails more than just smooth words:

"When the China plans became public there was a lot of unrest amongst the workers: if he goes to China, when will he start laying people off here? So when we were buying an oven for our Chinese subsidiary, I simultaneously bought one for the Dutch plant; demolished an old one and installed a new. You should not only show your commitment in words but also in actions. I could answer 'You're not suggesting I am closing down the plant next year when l've just invested a couple of 100 grand in new equipment?' Money talks in that sense, it's not just organization, you have to be aware of your internal communication as well."- Firm \#3.

\section{THE INFLUENCE OF EXTERNAL BUSINESS NETWORKS}

The discussion above has focused on the knowledge that is necessary for successful transnationalization by means of subsidiary establishment, and how this knowledge is routinized within the firm. This section focuses on what the relevance of the firm's external 
networks is in the acquisition of this knowledge. The collected narratives of transnationalization all come across individually as sequences of serendipitous events that incrementally lead to a transnationalized firm. These are entrepreneurial stories about meeting the right person at the right moment or suddenly getting a business contract from an unfamiliar source after which one thing leads to another. The relevance of this serendipity corroborates existing research (Harris \& Wheeler 2005; Agndal et al. 2008). However, to understand these events as mere 'historical accidents' would disregard the influence of an economic geography that is unevenly endowed with networks, knowledge and institutions (Stam 2010). Serendipitous entrepreneurship should be interpreted as a process of unintended discovery; the outcome of a combination of directed effort, contingency and prior knowledge (Dew 2009). Grabher (2004) points in this regard to the relevance of the position of a firm in a topological 'awareness space': you become aware by interacting with others in the firm's environment that are knowledgeable about how to engage in such a project. This leads to a focus on the traded and untraded interdependencies (Storper 1997) through which a firm gets directed towards the path of transnationalization and gradually becomes knowledgeable about entrepreneurial opportunities. What are the conditions- and spatiality- in which knowledge network formation occurs (Huber 2012)?

Interdependencies between firms give rise to what has been defined as 'buzz' (Storper \& Venables 2004): a specific learning ecology that keeps the actors involved 'in the loop' through 'local broadcasting'. Just by 'being' in a specific environment, firms can pick up signals and cues that reinforce an innovative trajectory. Buzz is not necessarily confined to the home region of the firm, for it has been shown that conferences, trade fairs and other 'temporary clusters' can be a substitute to buzz in the firm's immediate operating environment (Maskell et al. 2006). This is clearly expressed in the empirical findings. With 
the exception of firm \#10, which resides in a well-known Dutch high-tech cluster, the firm's home local environment was not found to be of particular significance for inter-firm knowledge acquisition. Instead, conferences and trade fairs provided functional equivalence. In general, the respondents noted that 'strategic information' is not something you can pick up from the air, even on conferences. Rather, buzz makes the entrepreneur aware of the possibilities, opportunities and threats of transnationalization. Buzz plays an important role in the dissemination of discourses on the future of the global economy. These discourses filter down in their sector-specific variety: "where is our industry moving to, would it be wise for me to join in?" As the respondent from firm \#3 noted, "people kept on saying that China is going to be the factory of the world and India is going to be the service center. Well, I'm a manufacturer so I started looking at China". Once having obtained that knowledge and discussing the idea within the business network, a friend of this respondent referred a Chinese intern to him that ended up as the firm's first BS. This illustrates the subtleties of the role of buzz and personal networks in a string of serendipitous events. Finally, it should be considered that once a firm has decided to investigate a possible transnationalization process, knowledge acquisition becomes an actively orchestrated effort by initiating a dialogue with other actors. Whereas the locus of buzz is still an important arena for this dialogue, knowledge transmission becomes less 'automatic' and more a specific outcome of directed action (Bathelt et al. 2004).

The examples above illustrate the kind of roles that actors in the firm's external network played in the transnationalization process. Most salient was that BS were usually recruited from the firm's business network. Moreover, in four of the eleven cases, the entrepreneurs' experience prior to establishing or becoming involved in the focal firm and their existing social networks provided important entry points to the foreign market (c.f. Huber 2009; Evers 2010). Equally important in three cases were BS accessed through, and eventually 
recruited from, Asian agents or distributors signaling the importance of such middle(wo)men in different stages of the transnationalization process (c.f. Hessels \& Terjesen 2010; Meyer et al. 2009). For half of the sample, connections from expatriate networks were an important knowledge source. And in six of the eleven cases other transnational firms, often large Original Equipment Manufacturers (OEMs), 'invited', the SME to transnationalize, often with the prospect of losing business otherwise (cf. Bathelt \& Glückler 2011). The physical co-location of firms did not really seem to matter for these network relations to occur (cf. Huber 2012). Inter-firm networks play an important role in providing the 'bridges' to transnationalization, but the relevant scale of these bridges is defined by the geography of the other actors that a focal firm interacts with, who are not necessary local (McDermott \& Taylor 1982; Van Meeteren 2013). The fact that local firms transnationalize together has more to do with established business linkages than their colocation per se. For example, nine respondents started to share knowledge on how to achieve transnationalization with other entrepreneurs within their networks. As such, we can infer that the more transnationalized the business network of an SME is, the higher its propensity to transnationalize itself. These examples confirm the importance of network embeddedness for the spread and diffusion of transnationalization knowledge. However, agency plays as much a role as an established network position. Once entrepreneurs have positively assessed the feasibility of transnationalization, they seem fully capable of sourcing the necessary knowledge themselves and build the necessary networks.

\section{CONCLUSIONS}

Referring to the discussion on an emerging knowledge based economy, Amin (2003, p.128) argues that: "It is wrong to assume that, like Superman, the free-floating knowledge worker alone has the remarkable powers to renew capitalism". Therefore, we have to reappreciate the "centrality of 'boring' old things such as socialization, sociability, work and 
the practices of doing, for knowledge creation, in order to understand contemporary economic change." This paper took up that challenge by investigating how individual Dutch SMEs learn to participate in what is arguably the biggest change in our contemporary economic system: the globalization of economic activity. This learning process exemplifies how transnationalization is an innovation. The central technology that needs to be mastered is essentially a sociological skill and mastery of that skill by a firm can be socially and geographically compared to the technological innovation processes that have been an important preoccupation for economic geography in the last two decades.

This study has focused in particular on two aspects that are deemed important in the academic literature on firm transnationalization. First, the knowledge, skills and routines that are necessary to allow an SME to gain societal embeddedness in a new context. Second, the role of the firm's network embeddedness for the acquisition of that knowledge. The article has shown how these different kinds of embeddedness provide analytically distinct perspectives on firm transnationalization, but it has simultaneously illustrated their degree of intertwinement

The core technology that needs to be implemented in an SME when establishing a foreign subsidiary is implicit or explicit acknowledgment that a firm has prior societal embeddedness in institutions and that these institutions influence how the firm will define the encountered situations. A firm is more likely to change these routines once it realizes the relativity of its own common sense. Becoming knowledgeable about other business systems is a process of learning by doing and quite often, learning by bumping. Entrepreneurship plays an active role in such transformations of internal firm routines, and the forging of communities of practice through which transnationalization knowledge is 
routinized and retained within the firm. BS in the host location of the firm are also crucial in transnationalization processes. These confidants operating on another continent are indispensable for both knowledge acquisition and community of practice formation.

Furthermore, based on the analysis of the individual serendipitous narratives of transnationalizing SMEs, it was found that firms learn important pieces of the sociological puzzle by taking cues from other firms that they interact with, and often get acquainted with the indispensable BS through these interactions. The intangible buzz that is emphasized in the geographical innovation literature in this regard primarily acts as a trigger initiating the innovation process. Afterwards, learning often occurs as the result of active inquiry by the focal entrepreneur, for example, in the context of business transactions. Moreover, once you 'know how' to do business in a particular environment, the 'know who' of network formation commonly follows from entrepreneurialism greased by a mutually profitable business proposition. However, ultimately reaping the benefits of that proposition occasionally requires learning by, and recovering from, bumping your head against a brick wall.

\section{REFERENCES}

AGNDAL, H., S. CHETTY \& H. WILSON (2008), Social Capital Dynamics and Foreign Market Entry. International Business Review 17, pp. 663-675.

AMIN, A. (2003), Spaces of Corporate Learning. In: J. PECK \& H.W-C YEUNG, eds., Remaking the Global Economy. pp. 114-130. Thousand Oaks/London/New York: Sage.

AMIN, A. \& P. COHENDET (2004), Architectures of Knowledge. Firms, Capabilities and Communities. Oxford: Oxford University Press. 
BATHELT, H. \& J. GLÜCKLER (2011), The Relational Economy. Oxford: Oxford University Press.

BATHELT H., A. MALMBERG \& P. MASKELL (2004), Clusters and Knowledge: Local Buzz, Global Pipelines and the Process of Knowledge Creation. Progress in Human Geography 28, pp. 31-56.

BATTILANA, J., LECA, B., \& E. BOXENBAUM, (2009), How Actors Change Institutions: Towards a Theory of Institutional Entrepreneurship. The Academy of Management Annals 3, pp. 65-107.

BERGER, P.L. \& T. LUCKMANN (1966), The Social Construction of Reality. A Treatise in the Sociology of Knowledge. Garden City, NY: Anchor Books.

BILKEY, W. \& G. TESAR (1977), The Export Behavior of Smaller-Sized Wisconsin Manufacturing Firms. Journal of International Business Studies 8, pp. 93-98.

BOSCHMA, R.A. (2005), Proximity and Innovation: a Critical Assessment. Regional Studies 39, pp. 61-74.

BOYER, R. (2005), How and Why Capitalisms Differ. Economy and Society 34, pp. 509557.

BUCKLEY, P.J. (1989), Foreign Direct Investment by Small and Medium Sized Enterprises: The Theoretical Background. Small Business Economics 1, pp. 89-100. CAVES, R. (2007), Multinational Enterprise and Economic Analysis, 3rd Edition. Cambridge: Cambridge University Press.

CHELL, E. (2004), Critical Incident Technique. In: C. CASSEL \& G. SYMON, eds., Essential Guide to Qualitative Methods in Organizational Research, pp. 45-61 London/Thousand Oaks/New Delhi: Sage.

CHETTY, S. \& D.B. HOLM (2000), Internationalisation of Small to Medium-Sized Manufacturing Firms: a Network Approach. International Business Review 9, pp. 7793. 
CLARK, G.L. (1998), Stylized Facts and Close Dialogue: Methodology in Economic Geography. Annals of the Association of American Geographers 88, pp. 73-87.

COE, N.M. \& T. BUNNELL (2003), 'Spatializing' Knowledge Communities: Towards a Conceptualization of Transnational Innovation Networks. Global Networks 3, pp. 437456.

COHEN, W \& D. LEVINTHAL (1990), Absorptive Capacity: a New Perspective on Learning and Innovation. Administrative Science Quarterly 35, pp. 128-152.

COVIELLO, N.E. \& A. MCAULEY (1999), Internationalization and the Smaller Firm: a Review of Contemporary Empirical Research. Management International Review 39, 223-256.

COVIELLO, N.E. \& H.J. MUNRO (1995), Growing the Entrepreneurial Firm. European Journal of Marketing 29, pp. 49-61.

DEW, N. (2009), Serendipity in Entrepreneurship. Organization Studies 30, 735-752.

DICKEN, P. (2011), Global Shift, Sixth Edition. New York/London: The Guilford Press.

DRORI, I., B. HONIG \& M. WRIGHT (2009), Transnational Entrepreneurship: an Emergent Field of Study. Entrepreneurship Theory and Practice 33, pp. 1001-1022.

ELLIS, P. (2000), Social Ties and Foreign Market Entry. Journal of International Business Studies 31, pp. 443-469.

EVERS, N. (2010), Factors Influencing the Internationalisation of New Ventures in the Irish Aquaculture Industry: an Exploratory Study. Journal of International Entrepreneurship 8, pp. 392-416.

FAULCONBRIDGE, J.R. (2006), Stretching Tacit Knowledge Beyond a Local Fix? Global Spaces of Learning in Advertising Professional Service Firms. Journal of Economic Geography 6, pp. 517-540.

FAULCONBRIDGE, J.R. (2007), Relational Knowledge Networks in Transnational Law Firms. Geoforum 38, pp. 925-940. 
GERRING, J. (2007), Case Study Research: Principles and Practices. Cambridge: Cambridge University Press.

GERTLER, M.S. (2001), Best Practice? Geography, Learning and the Institutional Limits to Strong Convergence. Journal of Economic Geography 1, pp. 5-26.

GERTLER, M.S. (2003), The Spatial Life of Things: the Real World of Practice Within the Global Firm. In: J. PECK \& H. W-C YEUNG, eds., Remaking the Global Economy, pp. 101-114. Thousand Oaks/London/New Delhi: Sage.

GERTLER, M.S. (2008), Buzz Without Being There? Communities of Practice in Context.

In: A. AMIN \& J. ROBERTS, eds., Community, Economic Creativity and Organization, pp. 203-227. Oxford: Oxford University Press.

GRABHER, G. (2004), Learning in Projects, Remembering in Networks?: Communality, Sociality, and Connectivity in Project Ecologies. European Urban and Regional Studies 11, pp. 103-123.

GRANOVETTER, M. (1985), Economic Action and Social Structure: The Problem of Embeddedness. American Journal of Sociology 91, pp. 481-510.

HARRIS, S. \& C. WHEELER (2005), Entrepreneurs' Relationships for Internationalization: Functions, Origins and Strategies. International Business Review 14, pp. 187-207. HESS, M, (2004), 'Spatial' Relationships? Towards a Reconceptualization of Embeddedness. Progress in Human Geography 28, 165-186.

HESSELS, J. (2005), Internationalization of Dutch SMEs. Zoetermeer: EIM.

HESSELS, J. \& S. TERJESEN (2010) Resource Dependency and Institutional Theory Perspectives on Direct and Indirect Export Choices. Small Business Economics 34, 203-220.

HOFSTEDE, G. (2001), Culture's Consequences. 2nd Edition. Thousand Oaks/London/New Delhi: Sage. 
HOGAN, B., J.A. CARRASCO \& B WELLMAN (2007), Visualizing Personal Networks: Working with Participant-aided Sociograms. Field Methods 19, pp. 116-144.

HUBER, F. (2009), Social Capital of Economic Clusters: Towards a Network-based Conception of Social Resources. Tijdschrift voor Economische en Sociale Geografie 100, pp.160-170.

HUBER, F. (2012), On the Sociospatial Dynamics of Personal Knowledge Networks: Formation, Maintenance, and Knowledge Interactions. Environment and Planning A 44, pp. 356-376.

HUGHES, N. (2009), Changing Faces: Adaptation of Highly Skilled Chinese Workers to a High-tech Multinational Corporation. The Journal of Applied Behavioral Science 45, pp. 212-238.

HYMER, S.H. (1976), The International Operations of National firms. Lexington MA: Lexington Books.

IBERT, O. (2010), Relational Distance: Sociocultural and Time-Spatial Tensions in Innovation Practices. Environment and Planning A 42, pp. 187-204.

JOHANSON, J \& J-E. VAHLNE (1977), The Internationalization Process of the Firm - A Model of Knowledge Development and Increasing Foreign Market Commitments. Journal of International Business Studies 8, pp. 23-32.

JOHANSON, J \& J-E. VAHLNE (2009), The Uppsala Internationalization Process Model Revisited: from Liability of Foreignness to Liability of Outsidership. Journal of International Business Studies 40, pp. 1411-1431.

JONES, A. \& J. T. MURPHY (2011), Theorizing Practice in Economic Geography: Foundations, Challenges, and Possibilities. Progress in Human Geography 35, pp. 366-392. 
KLOOSTERMAN, R.C. (2010), Matching Opportunities with Resources: a Framework for Analysing (Migrant) Entrepreneurship from a Mixed Embeddedness Perspective. Entrepreneurship \& Regional Development 22, pp. 25-45.

KOGUT, B. \& U. ZANDER (1993), Knowledge of the Firm and the Evolutionary Theory of the Multinational Corporation. Journal of International Business Studies 24, pp. 625645.

KOGUT, B. \& U. ZANDER (1996), What Firms Do? Coordination, identity, and learning. Organization science 7, pp. 502-518.

MASKELL, P. \& A. MALMBERG (2007), Myopia, Knowledge Development and Cluster Evolution. Journal of Economic Geography 7, pp. 603-618.

MASKELL, P., H. BATHELT \& A. MALMBERG (2006), Building Global Knowledge Pipelines: the Role of Temporary Clusters. European Planning Studies 14, pp. 9971013.

MATHEWS, J.A. \& I. ZANDER (2007), The International Entrepreneurial Dynamics of Accelerated Internationalisation. Journal of International Business Studies 38, pp. 387-403.

MCDERMOTT, P. \& M. TAYLOR (1982) Industrial Organization and Location. Cambridge: Cambridge University Press.

MEJRI, K. \& K. UMEMOTO (2010), Small- and Medium-Sized Enterprise Internationalization: Towards the Knowledge-Based Model. Journal of International Entrepreneurship 8, pp. 156-167.

MEYER, S., D. SCHILLER \& J. REVIELLA DIEZ (2009), The Janus-Faced Economy: Hong Kong Firms as Intermediaries Between Global Customers and Local Producers in the Electronics Industry. Tijdschrift voor Economische en Sociale Geografie 100, pp. 224-235. 
NELSON, R. R. \& S.G. WINTER (1982), An Evolutionary Theory of Economic Change. Cambridge MA/London: The Belknap Press of Harvard University Press.

NOOTEBOOM, B. (2000), Learning and Innovations in Organizations and Economies.

Oxford: Oxford University Press.

NOOTEBOOM, B (2008), Cognitive Distance in and Between Communities of Practice and

Firms: Where do Exploitation and Exploration Take Place, and How are They

Connected? In: A. AMIN \& J. ROBERTS, eds., Community, Economic Creativity and Organization, pp. 123-148. Oxford: Oxford University Press.

OECD (2008), Removing Barriers to SME Access to International Markets. Paris: OECD publishing.

OINAS P. (2006), The Many Boundaries of the Firm. In: M. TAYLOR \& P. OINAS, eds., Understanding the Firm. Spatial and Organizational Dimensions, pp. 35-61. Oxford: Oxford University Press.

OLIVER, C. (1991), Strategic Responses to Institutional Processes. Academy of Management Review 16, pp. 145-179.

PFLANZ, K. (2013), Seeking Opportunities: International Market Selection by European Engineering Consultancies. Tijdschrift voor Economische en Sociale Geografie 104, pp. $556-570$.

PRASHANTHAM, S. (2005), Toward a Knowledge-Based Conceptualization of Internationalization. Journal of International Entrepreneurship 3, pp. 37-52.

SCHOENBERGER, E. (1991), The Corporate Interview as a Research Method in Economic Geography. The Professional Geographer 43, pp. 180-189.

STAM, E. (2007), Why Butterflies don't Leave: Locational Behavior of Entrepreneurial Firms. Economic Geography 83, pp. 27-50. 
STAM, E. (2010), Entrepreneurship, Evolution and Geography. In: R.A. BOSCHMA \& R. MARTIN, eds., The Handbook of Evolutionary Economic Geography, pp. 139-162. Cheltenham: Edward Elgar.

STORPER, M. (1997), The Regional World. New York: The Guilford Press.

STORPER, M. \& A. VENABLES (2004), Buzz: Face-to-Face Contact and the Urban Economy. Journal of Economic Geography 4, pp. 351-370.

TOLSTOY, D. (2010), Network Development and Knowledge Creation Within the Foreign Market: A Study of International Entrepreneurial Firms. Entrepreneurship \& Regional Development 22, pp. 379-402.

UNCTAD (2010), World Investment Report. New York: United Nations Publishers.

VAN HOUTUM, H. (2002), Internationalisation and Mental Borders. Tijdschrift voor Economische en Sociale Geografie 90, pp. 329-335.

VAN MEETEREN, M. (2013), The Role of Agglomeration Economies for SME Transnationalization: Bypassing the Global Urban Service Nexus? in: C. Tamásy \& J. Revilla Diez, eds., Regional Resilience, Economy and Society, pp. 231-251. Farnham: Ashgate.

VERNON, R. (1979), The Product Cycle Hypothesis in a New International Environment. Oxford Bulletin of Economics and Statistics 41, 255-268.

WENGER, E (1998), Communities of Practice. Cambridge: Cambridge University Press.

WHITE, H., F. GODART \& V. CORONA (2007), Mobilizing Identities: Uncertainty and Control in Strategy. Theory, Culture \& Society 24, pp. 181-202.

WHITLEY, R. (1992), Business Systems in East Asia. Firms, Markets and Societies. Thousand Oaks/London/New York: Sage.

YEUNG, H.W-C. (2004), Chinese Capitalism in a Global Era. London/New York: Routledge. 
YEUNG, H.W-C. (2009), Transnationalizing Entrepreneurship: a Critical Agenda for Economic Geography. Progress in Human Geography 33, pp. 210-235. 